\title{
Investigation of the extraction process of spicy aromatic raw materials in the production of bitter tinctures
}

\author{
Natalia Popova, Taras Misyura, \\ Albina Rybachok, Valentyn Chornyi
}

National University of Food Technologies, Kyiv, Ukraine

Keywords:

Extraction

Hydromodule

Duration

Cardamom

Ginger

Pepper bitter

Article history:

Received 27.05.2017

Received in revised

form 21.06.2017

Accepted 05.09.2017

Corresponding

author:

Albina Rybachok

E-mail:

alai_ryb@ukr.net

DOI: $10.24263 / 2310-$

1008-2017-5-1-6

\section{Abstract}

Introduction. The research was conducted to determine the influence of the parameters of the extraction process on the extraction of target components from spices and aromatic raw materials for its intensification, and the ability of cardamom, ginger and red pepper to determine the accumulation of heavy metal ions was determined.

Materials and methods. The study of changes in the content of vitamin $\mathrm{C}$ and phenolic compounds in the extracts was carried out by titrometric and spectrophotometric methods. Determination of the ability to accumulate spicy aromatic raw materials of ions of heavy metals was carried out according to the schemes of complex formation of heavy metal ions with functional active groups.

Results and discussion. The optimum values of the relation and the length of the extraction process were respectively for cardamom 14.5 and $83 \mathrm{~min}$; for ginger -13 and 70 minutes; for bitter pepper - 17 and 92 minutes, provided that the process of extracting water as an extractant at a temperature of $40^{\circ} \mathrm{C}$ for maintaining vitamin $\mathrm{C}$ and constant mixing, due to the chemical composition of spicy aromatic raw materials.

The ability to accumulate metal ions of cardamom $\mathrm{Hg}^{2+}$, $\mathrm{Pb}^{2+}$ та $\mathrm{Cd}^{2+}$ is $94 \%, 66.52 \%$ and $72.57 \%$, for ginger $-92 \%$, $38.84 \%$ and $35.16 \%$, and for red bitter pepper - 94\%, $24.11 \%$ and $20.19 \%$ respectively. Cardamom, slightly lower ginger and red pepper are bitter in the ability to accumulate heavy metals, due to the presence in their composition of a significant amount of carbohydrates, vitamins, amino acids and pectin substances.

Conclusions. Research results can be effectively applied in the liquor industry to develop beverage formulations that would have high biological value and technological or hardware-technological schemes. 


\section{Introduction}

The production of bitter tinctures is becoming increasingly popular due to the use of various spices and aromatic herbal extracts in the formulation that give the finished drink harmonious organoleptic properties, so it can be noted that bitter tinctures have a positive effect on the human body, as is known tinctures - it is alcoholic drinks obtained by blending of infusions or extracts of various raw materials [1].

The traditional technology of the production of bitter tinctures involves infuse in containers for infuse over a period of 10-14 days on a water-alcohol mixture of $70 \%$ vol. Infuse is carried out by means of two showers, the duration of which varies from 5 to 7 days each. Then, in the blended tubs, the infusion is blended and brought to a strength of $40 \%$ vol [1].

Spicy aromatic raw material used in the production of bitter tinctures can be the most diverse, depending on the desired result. In our research, ginger, cardamom, red bitter pepper and honey were selected as raw material due to the rich chemical composition and excellent organoleptic properties.

One of the main benefits of using honey, ginger and cardamom extracts in the production of bitter infusions is the complex application of vitamins, glucose, fructose, enzymes, phenolic compounds, micro and macro elements with antioxidant and radioprotective properties.

It is recommended to use bitter tincture as a food of high biological value. Therefore, it is advisable to investigate the tread properties of the main components of bitter tinctures.

The addition of ginger and cardamom extracts to bitter tincture contributes to the enrichment of its vitamins, especially ascorbic acid. Also, it has now been proved that phenolic compounds that exhibit P-vitamin activity perform in a human body a number of important functions: they take part in the processes of formation of red blood cells erythrocytes, strengthen walls of vessels, are powerful antioxidants [1].

\section{Materials and methods}

During research, such spicy aromatic raw materials were selected as cardamom, ginger and red pepper bitter.

Ginger contains such substances as magnesium, phosphorus, sodium, silicon, potassium, manganese, calcium, chromium, iron, zinc, nicotinic acid, caprylic acid, oleic acid, linoleic acid, vitamin C, vitamins of group B, asparagine, choline. The aroma is spicy, astringent, due to the presence of essential oil (1-3\%), the taste - acute, burning, depends on the presence of phenol-like substance gingerola $-1.5 \%$ [2].

Cardamom contains the following substances: thiamine, riboflavin, pyridoxine, ascorbic acid, niacin equivalent. It is also noted for high calcium, magnesium, potassium, copper. Cardamom contains essential oil (4-7\%), which includes cineol, termineol, lemonoeol, and others [2].

As for spicy aromatic raw materials like red pepper bitter, it can be said that the most important part of pepper is alkaloid-like amide capsaicin, which has a very burning taste. The mass fraction of capsaicin in pepper varies from 0.5 to $1.5 \%$ depending on the species. 
However, red bell pepper contains mono- and disaccharides and a large amount of ascorbic acid, sodium and potassium [2].

In the role of extractant was selected prepared water and water-alcohol mixtures with a strength of $\mathbf{4 0 \%}$ vol. and $\mathbf{7 0 \%}$ vol. The choice of the extractant for the extraction process depended on the chemical nature of the substance removed from the spicy aromatic raw material.

Determination of the vitamin $\mathbf{C}$ content by the titration with a solution of 2,6dichlorophenolindophenolate sodium.

Determination of the content of phenolic compounds spectrophotometric method with post determination of phenolic compounds with the help of a calibration schedule for Gallic acid.

Method of determining the binding ability of spices and aromatic raw materials powders for metal ions. To the inoculum powder of the spicy aromatic raw material under study, $50 \mathrm{~cm}^{3}$ of warm $\left(45-50{ }^{\circ} \mathrm{C}\right)$ distilled water was added, stirred and left for 10 minutes to swell. To the resulting mixture was added $1 \mathrm{~cm}^{3}$ of $0.1 \mathrm{~mol} / \mathrm{dm}^{3}$ solution of the salt of the test metal, stirred for 1 hour on a magnetic stirrer, filtered through a folded filter. In the filtrate, the content of ions of the investigated metals was determined by the calibration graph method. The amount of $\mathrm{Pb}$ (II), $\mathrm{Hg}$ (II), Cd (II) absorbed by the main components of spicy aromatic raw material was determined as the difference between $\mathrm{m}_{\mathrm{Pb}, \mathrm{Cd}, \mathrm{Hg}}$ and $\mathrm{m}_{\mathrm{Pb}, \mathrm{Cd} \text {, }}$ $\mathrm{Hg}$, which was found in the filtrate. $\mathrm{pH}$ of solutions was created using cristal urotropin [].

Processing of experimental data. To obtain and analyze experimental data, a multivariate experiment of type $2^{2}$ was planned and mathematical and statistical methods of research, methods for determination of vitamin $\mathrm{C}$ and phenolic compounds were used. For the processing of experimental data, experimental and statistical methods of mathematical modeling were used. In order to find the optimal values of the process parameters, an experiment plan of type $\mathrm{N}=3^{\mathrm{n}}$ was planned and implemented to obtain the second order regression equation.

\section{Results and discussions}

Determination of the ability to accumulate spicy aromatic raw materials of heavy metal ions. During the study of the tread properties of spicy aromatic raw materials, the following data were obtained, which are presented in Table 1.

Table 1

Data on tread properties of spicy aromatic raw materials

\begin{tabular}{|c|c|c|c|c|}
\hline \multirow[t]{2}{*}{ № } & \multirow[t]{2}{*}{$\begin{array}{c}\text { Name of powder of spicy aromatic raw } \\
\text { materials }\end{array}$} & \multicolumn{3}{|c|}{$\begin{array}{c}\text { Ability to accumulate metal } \\
\text { ions, } \%\end{array}$} \\
\hline & & $\mathbf{P b}^{2+}$ & $\mathrm{Cd}^{2+}$ & $\mathbf{H g}^{2+}$ \\
\hline 1 & Cardamom & 94 & 66,52 & 72,57 \\
\hline 2 & Ginger & 92 & 38,84 & 35,16 \\
\hline 3 & Red pepper bitter & 94 & 24,11 & 20,19 \\
\hline
\end{tabular}


Based on Table 1, high tread properties are cardamom, slightly lower ginger and red pepper bitter.

The sorptive properties of heavy metal ions of ginger powder are due to the presence of a significant amount of carbohydrates and vitamin $\mathrm{C}$ in its composition. Complex formation occurs with pectin substances and vitamin $\mathrm{C}$ due to the substitution of hydrogen in hydroxyl groups with the formation of 4-membered cycles.

The protective properties of heavy metal ions of cardamom powder are carried out in 3 schemes of complex formation, namely amino acid fragments, with pectin substances and vitamins.

Protective properties concerning heavy metal ions of red bitter pepper powder are complexed with vitamin $\mathrm{C}$, while the coordination of metal ions will be carried out by oxygen atoms due to the substitution of hydrogen in hydroxyl groups with the formation of 4-membered cycles $[5,6]$.

\section{Investigation of the influence of extraction parameters on the output of the target components}

Due to the fact that in the production of bitter tinctures raw material containing vitamin $\mathrm{C}$ is destroyed under the influence of high temperatures, the temperature of the extraction process of $40{ }^{\circ} \mathrm{C}$ was chosen for research, which intensifies the process and preserves all the useful substances [7].

The extraction process was carried out in flasks on the vibration stand, with correlation 10,15 and 20. The mixing frequency was $100 \mathrm{rpm}$. As an extractant, water, water-alcoholic mixture of $40 \%$ vol. and $70 \%$ vol. is selected. Guided by the chemical composition as a vegeTable raw material was taken cardamom, ginger and red pepper bitter. These spices contain a significant amount of vitamin $\mathrm{C}$ and phenolic compounds and are used in the production of bitter tinctures.

The chemical composition of the extracts obtained from dry vegeTable raw materials is given in Table 2.

The data in Table 2 indicate a higher yield of phenolic compounds from spicy aromatic raw materials in a water-alcoholic mixture of $40 \%$ vol.

The influence of the type of raw material on the chemical composition of the extracts was considered, in the first case, the dry powders, the extraction data of which is given in Table 7, as well as fresh raw materials. When using fresh raw materials in terms of dry matter, the data were given, which are given in Table 3.

In this case, cardamom was not investigated, since this spice is used only in dry form. The correlation 10 created hydrodynamic conditions that prevented a full-fledged biologically active substances exit to the extractor and it was not advisable to carry it out. Summarizing the obtained data on the release of vitamin $\mathrm{C}$ and phenolic substances into the extractant, one can conclude that there is no significant difference in the kind of raw material (dry, fresh), therefore, for saving and convenience, for further research, dry powders were used.

The choice of the optimal correlation was based on the percentage of satisfaction in vitamin $\mathrm{C}$ for the products of the healing effect. Satisfaction with vitamin $\mathrm{C}$ was calculated taking into account the daily use of bitter tincture $-80 \mathrm{ml}$, and the daily needs of the population in vitamin $\mathrm{C}-75 \mathrm{mg} / \mathrm{day}$. While satisfaction with vitamin $\mathrm{C}$ should be $10-50 \%$ $[7,8]$, as presented in Table 4. 
Chemical composition of the extracts obtained from dry powders

\begin{tabular}{|c|c|c|c|c|}
\hline Sample name & Indicator & $\begin{array}{c}\text { Cardamom } \\
\text { extract }\end{array}$ & $\begin{array}{l}\text { Ginger } \\
\text { extract }\end{array}$ & $\begin{array}{c}\text { Red } \\
\text { pepper } \\
\text { bitter } \\
\text { extract }\end{array}$ \\
\hline \multirow[t]{2}{*}{$\begin{array}{l}\text { Correlation } 20 \text {, } \\
\text { extractor - water }\end{array}$} & $\begin{array}{l}\text { Concentration of phenolic } \\
\text { substances, } \mathrm{mg} / \mathrm{dm}^{3}\end{array}$ & 85,12 & 140,73 & 220,59 \\
\hline & $\begin{array}{l}\text { Ascorbic acid content, } \\
\mathrm{mg} / 100 \mathrm{ml}\end{array}$ & 8,36 & 7,92 & 16,28 \\
\hline \multirow{2}{*}{$\begin{array}{l}\text { Correlation } 20 \text {, } \\
\text { extractor - water- } \\
\text { alcohol mixture of } \\
40 \% \text { vol. }\end{array}$} & $\begin{array}{l}\text { Concentration of phenolic } \\
\text { substances, } \mathrm{mg} / \mathrm{dm}^{3}\end{array}$ & 105,08 & 374,59 & 421,65 \\
\hline & $\begin{array}{l}\text { Ascorbic acid content, } \\
\mathrm{mg} / 100 \mathrm{ml}\end{array}$ & 7,92 & 10,12 & 13,2 \\
\hline \multirow[t]{2}{*}{$\begin{array}{l}\text { Correlation } 15 \text {, } \\
\text { extractor - water }\end{array}$} & $\begin{array}{l}\text { Concentration of phenolic } \\
\text { substances, } \mathrm{mg} / \mathrm{dm}^{3}\end{array}$ & 154,99 & 231,99 & 395,98 \\
\hline & $\begin{array}{l}\text { Ascorbic acid content, } \\
\mathrm{mg} / 100 \mathrm{ml}\end{array}$ & 9,24 & 7,92 & 13,64 \\
\hline \multirow{2}{*}{$\begin{array}{l}\text { Correlation } 15 \text {, } \\
\text { extractor - water- } \\
\text { alcohol mixture of } \\
40 \% \text { vol. }\end{array}$} & $\begin{array}{l}\text { Concentration of phenolic } \\
\text { substances, } \mathrm{mg} / \mathrm{dm}^{3}\end{array}$ & 294,74 & 530,02 & 597,04 \\
\hline & $\begin{array}{l}\text { Ascorbic acid content, } \\
\mathrm{mg} / 100 \mathrm{ml}\end{array}$ & 11,44 & 11,0 & 8,8 \\
\hline \multirow{2}{*}{$\begin{array}{l}\text { Correlation } 15, \\
\text { extractor - water- } \\
\text { alcohol mixture of } \\
70 \% \text { vol. }\end{array}$} & $\begin{array}{l}\text { Concentration of phenolic } \\
\text { substances, } \mathrm{mg} / \mathrm{dm}^{3}\end{array}$ & 73,70 & 434,48 & 143,58 \\
\hline & $\begin{array}{l}\text { Ascorbic acid content, } \\
\mathrm{mg} / 100 \mathrm{ml}\end{array}$ & 8,36 & 9,24 & 13,2 \\
\hline \multirow[t]{2}{*}{$\begin{array}{l}\text { Correlation } 10 \text {, } \\
\text { extractor - water }\end{array}$} & $\begin{array}{l}\text { Concentration of phenolic } \\
\text { substances, } \mathrm{mg} / \mathrm{dm}^{3}\end{array}$ & 177,81 & 377,44 & 621,28 \\
\hline & $\begin{array}{l}\text { Ascorbic acid content, } \\
\mathrm{mg} / 100 \mathrm{ml}\end{array}$ & 13,2 & 26,5 & 17,6 \\
\hline \multirow{2}{*}{$\begin{array}{l}\text { Correlation } 10 \text {, } \\
\text { extractor - water- } \\
\text { alcohol mixture of } \\
40 \% \text { vol. }\end{array}$} & $\begin{array}{l}\text { Concentration of phenolic } \\
\text { substances, } \mathrm{mg} / \mathrm{dm}^{3}\end{array}$ & 400,24 & 699,71 & 836,60 \\
\hline & $\begin{array}{l}\text { Ascorbic acid content, } \\
\mathrm{mg} / 100 \mathrm{ml}\end{array}$ & 11,0 & 17,73 & 14,96 \\
\hline
\end{tabular}

These tables show that, given the satisfaction with vitamin $\mathrm{C}$, the correlation 10 is optimal. As for extractants, good indicators give a water-alcohol mixture $40 \%$ vol., and water-alcohol mixture $70 \% \mathrm{vol}$. is not appropriate, since the percentage of satisfaction in vitamin $\mathrm{C}$ below $10 \%$. Such an extractant as water is very interesting, as satisfaction with vitamin $\mathrm{C}$ is low, but there is a way to increase it, namely, to evaporate excess moisture and obtain an aqueous concentrate.

Consequently, for obtaining qualitative vitamin C-rich extracts, it is necessary to adhere to the following extraction conditions from spices and aromatic herbs:

- the duration of the process should be 80 minutes at constant stirring at a frequency of $100 \mathrm{rpm}$;

- $\quad$ the extraction temperature should not exceed $40{ }^{\circ} \mathrm{C}$. 
Chemical composition of extracts from fresh raw materials

\begin{tabular}{|c|c|c|c|c|}
\hline Sample name & Indicator & $\begin{array}{c}\text { Cardamom } \\
\text { extract }\end{array}$ & $\begin{array}{l}\text { Ginger } \\
\text { extract }\end{array}$ & $\begin{array}{c}\text { Red pepper } \\
\text { extract bitter }\end{array}$ \\
\hline \multirow{2}{*}{$\begin{array}{l}\text { Correlation 20, } \\
\text { extractant - } \\
\text { water }\end{array}$} & $\begin{array}{l}\text { Concentration of } \\
\text { phenolic substances, } \\
\mathrm{mg} / \mathrm{dm}^{3}\end{array}$ & - & 120,78 & 173,53 \\
\hline & $\begin{array}{l}\text { Ascorbic acid content, } \\
\mathrm{mg} / 100 \mathrm{ml}\end{array}$ & - & 7,92 & 10,56 \\
\hline \multirow{2}{*}{$\begin{array}{l}\text { Correlation 20, } \\
\text { extractant - } \\
\text { water-alcohol }\end{array}$} & $\begin{array}{l}\text { Concentration of } \\
\text { phenolic substances, } \\
\mathrm{mg} / \mathrm{dm}^{3}\end{array}$ & - & 361,76 & 542,85 \\
\hline & $\begin{array}{l}\text { Ascorbic acid content, } \\
\mathrm{mg} / 100 \mathrm{ml}\end{array}$ & - & 8,8 & 13,2 \\
\hline \multirow{2}{*}{$\begin{array}{l}\text { Correlation } 15 \text {, } \\
\text { extractant - } \\
\text { water }\end{array}$} & $\begin{array}{l}\text { Concentration of } \\
\text { phenolic substances, } \\
\mathrm{mg} / \mathrm{dm}^{3}\end{array}$ & - & 249,10 & 172,10 \\
\hline & $\begin{array}{l}\text { Ascorbic acid content, } \\
\mathrm{mg} / 100 \mathrm{ml}\end{array}$ & - & 7,92 & 9,68 \\
\hline \multirow{2}{*}{$\begin{array}{l}\text { Correlation } 15 \text {, } \\
\text { extractant - } \\
\text { water-alcohol }\end{array}$} & $\begin{array}{l}\text { Concentration of } \\
\text { phenolic substances, } \\
\mathrm{mg} / \mathrm{dm}^{3}\end{array}$ & - & 127,90 & 511,48 \\
\hline & $\begin{array}{l}\text { Ascorbic acid content, } \\
\mathrm{mg} / 100 \mathrm{ml}\end{array}$ & - & 8,8 & 11,44 \\
\hline
\end{tabular}

These conditions will enable us to intensify the extraction process and obtain extracts that will be used in the production of bitter tinctures. Given that in the method of obtaining a bitter tincture there is a process of concentration of water extracts, it would be advisable to compare the chemical composition of water extracts and concentrates from them, the data are given in Table 5.

The data in Table 5 indicate that the extraction concentration step allows increasing the content of biologically active substances, thereby increasing the biological value of the beverage. On the basis of the research, a new method of obtaining bitter tinctures was developed.

In the developed method, the replacement of the water-alcohol mixture with the prepared water can be explained by the fact that extraction of water results in a greater amount of vitamin $\mathrm{C}$, as well as during the blending, the possibility of enriching the finished vitamin $\mathrm{C}$ with the concentration of the extracts is possible. At the same time, the costs of alcohol for extraction are excluded.

The duration of the extraction process should ensure the maximum yield of biologically active substances. Conducting the extraction process for more than 120 minutes is not feasible, since the extracts are contaminated by adjacent compounds, the diffusion rate of which is much smaller than that of biologically active substances. And the duration of less than 40 minutes does not allow the maximum removal of biologically active substances. 
Table 4

Satisfaction in vitamin $\mathrm{C}$ with bitter tinctures

\begin{tabular}{|c|c|c|c|c|c|c|}
\hline \multirow[b]{2}{*}{$\begin{array}{c}\text { Sample } \\
\text { name }\end{array}$} & \multicolumn{3}{|c|}{ Ingredients of the formulation } & \multirow{2}{*}{$\begin{array}{c}\text { Content of } \\
\text { ascorbic } \\
\text { acid in } \\
\text { extracts, } \\
\text { mg/100 ml }\end{array}$} & \multirow{2}{*}{$\begin{array}{c}\text { Content of } \\
\text { ascorbic acid } \\
\text { in water- } \\
\text { alcohol } \\
\text { mixtures is } \\
40 \% \text { vol., } \\
\text { mg/100 ml } \\
\end{array}$} & \multirow[b]{2}{*}{$\begin{array}{c}\text { Satisfaction } \\
\text { in ascorbic } \\
\text { acid, \% }\end{array}$} \\
\hline & $\begin{array}{c}\text { Cardamom } \\
\text { extract }\end{array}$ & $\begin{array}{l}\text { Ginger } \\
\text { extract }\end{array}$ & $\begin{array}{c}\text { Red } \\
\text { pepper } \\
\text { extract } \\
\text { bitter }\end{array}$ & & & \\
\hline \multirow{4}{*}{$\begin{array}{l}\text { Correlation } \\
20, \\
\text { extractant - } \\
\text { water }\end{array}$} & 2 & 1 & 3 & 12,25 & 5,25 & 5,6 \\
\hline & 3 & 1 & 2 & 10,93 & 4,68 & 5,0 \\
\hline & 4 & 1 & 1 & 9,61 & 4,12 & 4,39 \\
\hline & 1 & 1 & 4 & 13,57 & 5,81 & 6,2 \\
\hline \multirow{4}{*}{$\begin{array}{l}\text { Correlation } \\
20 \text {, } \\
\text { extractant - } \\
\text { water- } \\
\text { alcohol } \\
40 \% \text { vol. }\end{array}$} & 2 & 1 & 3 & 10,93 & - & 11,66 \\
\hline & 3 & 1 & 2 & 10,05 & - & 10,72 \\
\hline & 4 & 1 & 1 & 9,17 & - & 9,78 \\
\hline & 1 & 1 & 4 & 11,81 & - & 12,59 \\
\hline \multirow{4}{*}{$\begin{array}{l}\text { Correlation } \\
15, \\
\text { extractant - } \\
\text { water }\end{array}$} & 2 & 1 & 3 & 11,22 & 4,81 & 5,13 \\
\hline & 3 & 1 & 2 & 10,49 & 4,49 & 4,79 \\
\hline & 4 & 1 & 1 & 9,75 & 4,18 & 4,46 \\
\hline & 1 & 1 & 4 & 11,95 & 5,12 & 5,46 \\
\hline \multirow{4}{*}{$\begin{array}{l}\text { Correlation } \\
15 \text {, } \\
\text { extractant - } \\
\text { water- } \\
\text { alcohol } \\
40 \% \text { vol. }\end{array}$} & 2 & 1 & 3 & 10,05 & - & 10,72 \\
\hline & 3 & 1 & 2 & 10,49 & - & 11,19 \\
\hline & 4 & 1 & 1 & 10,93 & - & 11,66 \\
\hline & 1 & 1 & 4 & 9,61 & - & 10,25 \\
\hline \multirow{4}{*}{$\begin{array}{l}\text { Correlation } \\
15 \text {, } \\
\text { extractant - } \\
\text { water- } \\
\text { alcohol } \\
70 \% \text { vol. }\end{array}$} & 2 & 1 & 3 & 10,93 & 6,24 & 5,6 \\
\hline & 3 & 1 & 2 & 10,12 & 5,78 & 5,0 \\
\hline & 4 & 1 & 1 & 9,31 & 5,32 & 4,39 \\
\hline & 1 & 1 & 4 & 11,73 & 6,70 & 6,2 \\
\hline \multirow{4}{*}{$\begin{array}{l}\text { Correlation } \\
10 \text {, } \\
\text { extractant - } \\
\text { water- } \\
\text { alcohol } \\
40 \% \text { vol. }\end{array}$} & 2 & 1 & 3 & 17,20 & 7,37 & 11,66 \\
\hline & 3 & 1 & 2 & 16,89 & 7,24 & 10,72 \\
\hline & 4 & 1 & 1 & 16,16 & 6,92 & 9,78 \\
\hline & 1 & 1 & 4 & 18,36 & 7,87 & 12,59 \\
\hline \multirow{4}{*}{$\begin{array}{l}\text { Correlation } \\
10, \\
\text { extractant - } \\
\text { water }\end{array}$} & 2 & 1 & 3 & 15,04 & - & 16,04 \\
\hline & 3 & 1 & 2 & 13,74 & - & 14,66 \\
\hline & 4 & 1 & 1 & 12,45 & - & 13,28 \\
\hline & 1 & 1 & 4 & 16,33 & - & 17,42 \\
\hline
\end{tabular}


Table 5

Chemical composition of water extracts and concentrates from spicy aromatic raw materials

\begin{tabular}{|c|c|c|c|c|c|c|c|}
\hline \multirow{2}{*}{$№$} & \multirow{2}{*}{$\begin{array}{c}\text { Name of the } \\
\text { raw material }\end{array}$} & \multicolumn{2}{|c|}{$\begin{array}{c}\text { Content of vitamin } \\
\mathrm{C}, \mathrm{mg} / 100 \mathrm{ml}\end{array}$} & \multicolumn{2}{c|}{$\begin{array}{c}\text { Content of phenolic } \\
\text { compounds, mg/100 ml }\end{array}$} & \multicolumn{2}{c|}{$\begin{array}{c}\text { Dry matter } \\
\text { content, \% }\end{array}$} \\
\cline { 3 - 8 } & & $\mathrm{I}$ & $\mathrm{II}$ & $\mathrm{I}$ & $\mathrm{II}$ & $\mathrm{I}$ & II \\
\hline 1 & Cardamom & 12,76 & 24,16 & 89,40 & 156,42 & 1 & 2,5 \\
\hline 2 & Ginger & 25,65 & 32,12 & 301,87 & 508,63 & 3,3 & 4,5 \\
\hline 3 & $\begin{array}{c}\text { Red pepper } \\
\text { bitter }\end{array}$ & 16,72 & 21,82 & 662,64 & 823,77 & 3,5 & 8,5 \\
\hline
\end{tabular}

Note. I - extracts; II - concentrated extracts

The temperature of $40{ }^{\circ} \mathrm{C}$ will accelerate the extraction process and preserve vitamin $\mathrm{C}$ containing vegeTable raw materials. The temperature below $35{ }^{\circ} \mathrm{C}$ will not ensure the complete removal of biologically active substances, and temperatures above $45{ }^{\circ} \mathrm{C}$ will contribute to the destruction of vitamin $\mathrm{C}$.

When stirred, the extraction rate increases, as the layer of the non-volatile fluid decreases and convectional streams are created that facilitate the transfer of matter to the extractor.

\section{Mathematical and statistical processing of data}

The vast majority of investigated objects belong to a class of complex systems characterized by a large number of interconnected parameters. In conditions of selection of optimal parameters of the process of extraction, the issue is solved by means of experimental statistical methods [9].

Having determined what factors influence the content of phenolic compounds and vitamin $\mathrm{C}$ in extracts of spicy aromatic raw materials, we determined their levels of variation, which are given in Table 6 and constructed the matrix of the two-factor experiment.

\section{Levels of variation}

Table 6

\begin{tabular}{|l|c|c|c|c|}
\hline Factor & Unit of measurement & 0-level & Upper level «+» & Lower level «-» \\
\hline Correlation & & 15 & 20 & 10 \\
\hline Duration & min & 80 & 120 & 40 \\
\hline
\end{tabular}

A coherent comparison of the values of the main factors for each target component made it possible to determine the optimal values of process parameters for each type of raw material. 

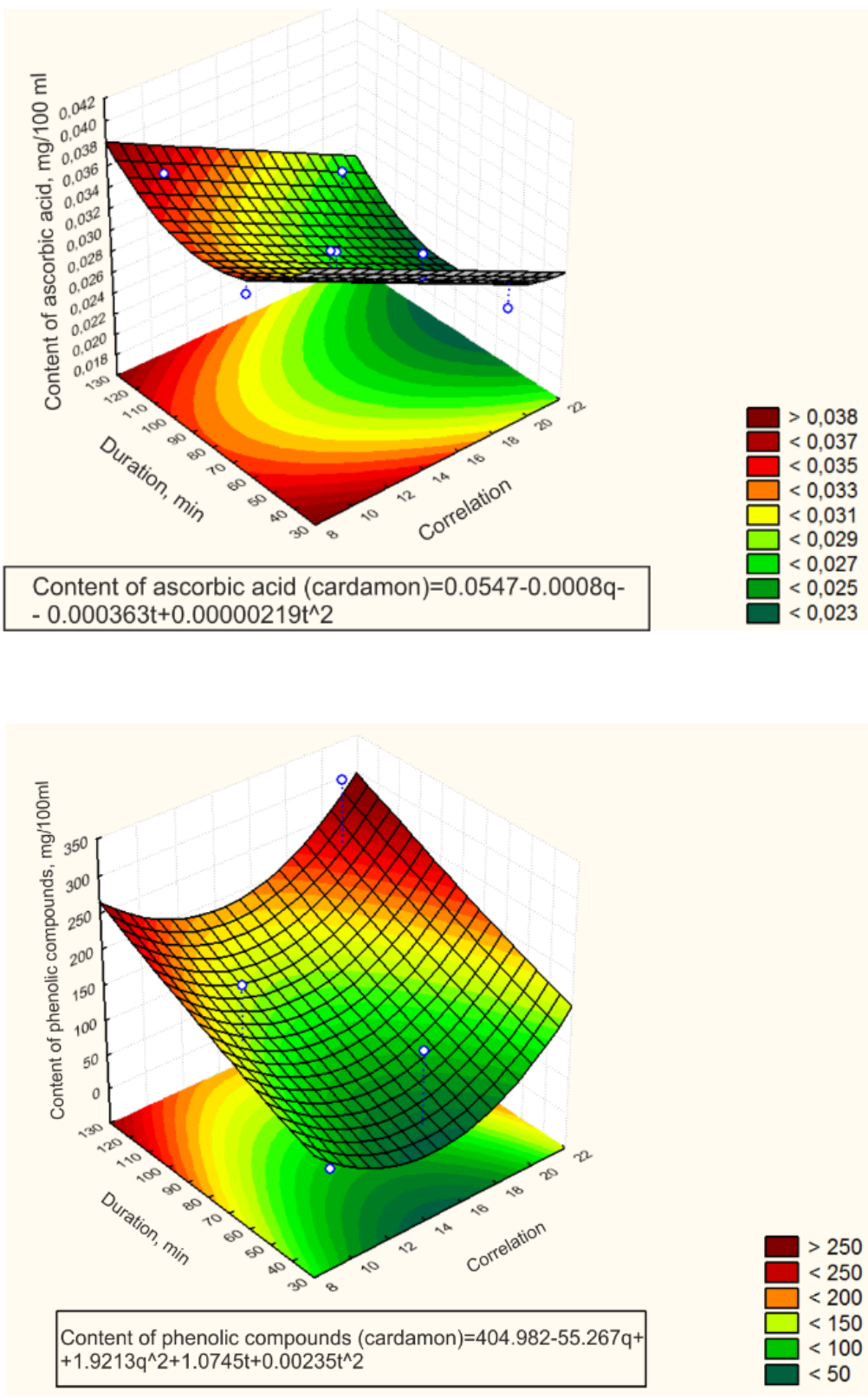

Figure 1. Surfaces of the response to the dependence of vitamin $C$ and phenolic compounds on the correlation and the duration of the extract in cardamom 

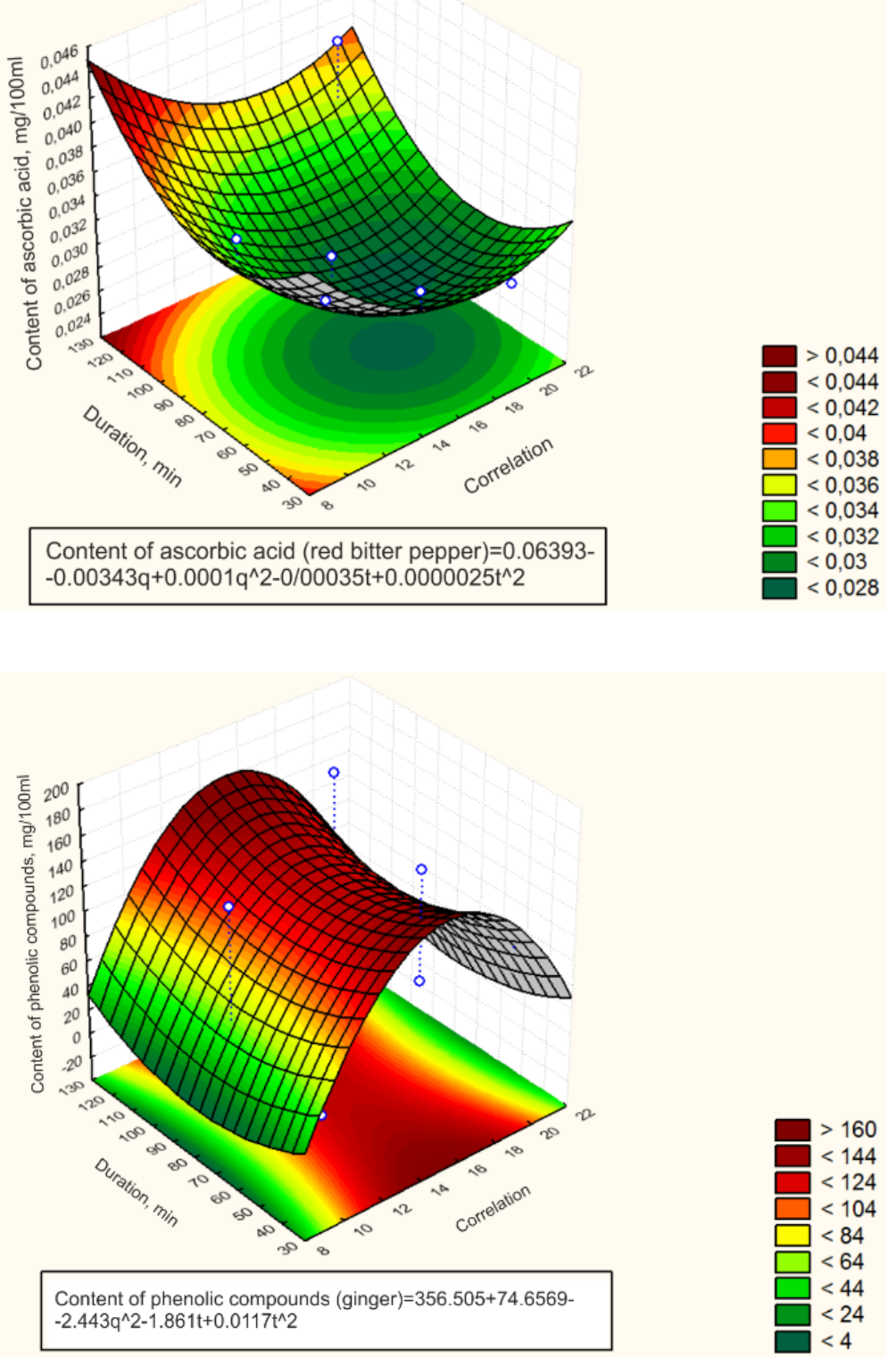

Figure 2.Results of the response of the dependence of the content of vitamin $C$ and phenolic compounds on the correlation and the duration of the extract from red bitter pepper 

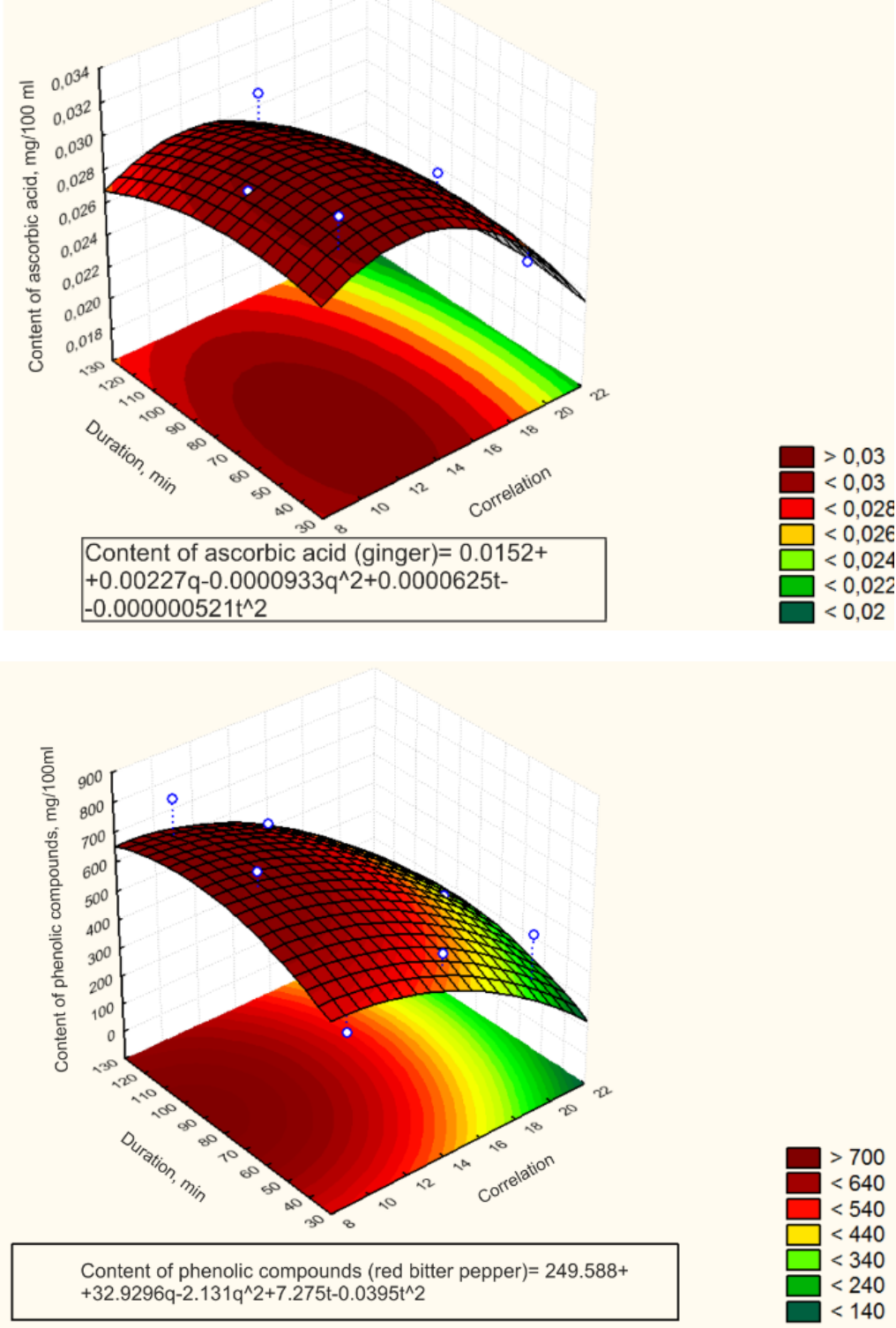

Figure 3. Surfaces of the response of the dependence of the content of vitamin $C$ and phenolic compounds on the correlation and duration of the extract in ginger

Thus, the optimal values of the correlation and the length of the extraction process were respectively for cardamom 14.5 and 83 min (Figure 1); for ginger -13 and 70 minutes (Figure 2); for pepper bitter 17 and 92 minutes (Figure 3). 


\section{Conclusion}

Taking into account the above we can conclude that it is advisable to consider such a parameter of nutritional value as the ability of the main components and food additives to bind toxic metals ( $\mathrm{Pb}$ (II), $\mathrm{Cd}$ (II), $\mathrm{Hg}$ (II)) when developing tincture formulations and withdraw them after digestion of food from the human body. To do this, it is necessary to select the following types of raw materials that would have this indicator.

Also presented are the results of scientific research in the liqueur industry, namely in the technology of production of bitter tinctures based on extracts of cardamom, ginger and red pepper.

To evaluate the tread properties of extracts, we first studied the ability of the components of it to bind ions $\mathrm{Pb}^{+2}, \mathrm{Cd}^{+2}, \mathrm{Hg}^{+2}$. Protective properties concerning heavy metal ions of spices and aromatic raw powders are carried out in 3 schemes of complex formation, namely amino acid fragments, with pectin substances and vitamins.

Based on the research data, when developing the formulation of alcoholic beverages, it is recommended to be guided by the data obtained to create products of high biological value.

Also, the selection of optimal parameters of the extraction process, namely, the correlation and the duration, have been carried out. It was found out that in order to obtain high quality extracts, the optimum values of the correlation and the length of the extraction process should be 14.5 and 83 min respectively for cardamom; for ginger - 13 and 70 minutes; for pepper red bitter 17 and 92 minutes.

The technology of production of bitter tinctures is described and the hardwaretechnological scheme of production of bitter tinctures has been developed, which will provide in-depth extraction of biologically active substances from spicy aromatic raw materials, increase of biological value, shortening of the process duration, decrease of alcohol consumption and processing of swirling without additional evaporation of alcohol, obtaining at the output ready drink.

\section{References}

1. Domaretskiy, V. A., Ostapchuk, M. V., Ukrayinets, I. A. (2003), Tehnologiya harchovih produktiv, NUHT, Kyiv.

2. Hartwig Schulz (2004), Analysis of coffee, tea, cocoa, tobacco, spices, medicinal and aromatic plants, and related products. Near-Inrared Spectroscopy in Agriculture, Agronomy Monograph,44. p. 345.

3. Das P., Samantaray S., Rout G.R. (2013), Studies on cadmium toxicity in plants: A Review, Environmental Pollution, 98(1), pp. 29-36.

4. Gutierrez I.H., Lorenzo E. Sanchez-Palomo, Espinosa A. Vicario (2005), Phenolic composition and magnitude of copigmentation in young and shortly aged red wines made from the cultivars, Cabernet Sauvignon, Cencibel and Syrah, Food Chemistry, 92, pp. 269-283, DOI:10.1016/j.foodchem.2004.07.023

5. Knöss W., Stolte F. (2009), Community Herbal Monograph on Gentian lutea L., Radix, European Medicines Agency, London.

6. Rybachok A.V., Chorniy V.M., Misyura T.G., Popova N.V. (2015), Intensifikatsiya protsesu ekstraguvannya pri virobnitstvi girkih nastoyanok, [The intensification of the extraction process in the production of bitter liqueurs], Naukovi pratsi, 47, pp. 75-78. 
7. Kemper F.H. (2003), ESCOP Monographs. The Scientific Foundation for the Herbal Medicinal Products, Thieme, Stuttgart.

8. Olivier,D.K. and B.-E. van Wyk (2013), Bitterness values for traditional tonic plants of southern Africa, Journal of Ethnopharmacology, 3(147), pp. 676-679, DOI:10.1016/j.jep.2013.03.059.

9. Heinrich M., Barnes J., Gibbons S., Williamson E.M. (2012), Fundamentals of Pharmacognosy and Phytotherapy, Churchill Livingstone, Edinburgh.

10. Gutierrez I.H., Sanchez-Palomo Lorenzo E., Vicarion Espinosa E. (2005), Phenolic composition and magnitude of copigmentation in young and shortly aged red wines made from the culitivars, Food Chemistry, 92, pp. 269-283. 